\title{
RESPONSE OF OKRA BASED ON ELECTROPHYSIOLOGICAL MODELING UNDER SALT STRESS AND RE-WATERING
}

\section{RESPOSTA DO OKRA COM BASE EM MODELAGEM ELETROFISIOLÓGICA SOB STRESS DE SAL E RE-WATERING}

\section{Ahmad AZEEM ${ }^{1}$; Yanyou WU ${ }^{2}$; Qaiser JAVED ${ }^{3}$; Deke XING ${ }^{4}$; Ikram ULLAH ${ }^{5}$; Francis KUMI ${ }^{6}$}

1. Key Laboratory of Modern Agricultural Equipment and Technology, Ministry of Education, Institute of Agricultural Engineering, Jiangsu University, Zhenjiang, Jiangsu, P.R China 2.(corresponding author) Research Centre for Environmental Bio-Science and Technology, State Key Laboratory of Environmental Geochemistry, Institute of Geochemistry, Chinese Academy of Sciences, Guiyang, Guizhou, P.R China wuyanyou@mail.gyig.ac.cn; 3. Key Laboratory of Modern Agricultural Equipment and Technology, Ministry of Education, Institute of Agricultural Engineering, Jiangsu University, Zhenjiang, Jiangsu, P.R China; 4. Key Laboratory of Modern Agricultural Equipment and Technology, Ministry of Education, Institute of Agricultural Engineering, Jiangsu University, Zhenjiang, Jiangsu, P.R China; 5. Key Laboratory of Modern Agricultural Equipment and Technology, Ministry of Education, Institute of Agricultural Engineering, Jiangsu University, Zhenjiang, Jiangsu, P.R China; 6. Key Laboratory of Modern Agricultural Equipment and Technology, Ministry of Education, Institute of Agricultural Engineering, Jiangsu University, Zhenjiang, Jiangsu, P.R China

\begin{abstract}
In this study, two okra cultivars, Chinese green and Chinese red were used to assess the water status and growth parameters subjected to salt stress by adding $\mathrm{NaCl}$ and $\mathrm{CaCl}_{2}$ with same proportion in Hoagland culture solution at levels of $0 \%, 0.6 \%, 1.2 \%, 1.8 \%$ and re-watering at levels of $0.6-0 \%, 1.2-0.6 \%, 1.8-1.2 \%$. The measured water potential and physiological capacitance values were used to calculate leaf tensity. Salt stress significantly reduced growth and water status parameters. Chinese green showed more reduction as compared to Chinese red but at $1.8 \%$ salt stress reduction of both cultivars were almost same. Re-watering had given a positive response for both cultivars to recover from higher salt stress. Dry weight, physiological capacitance, leaf tensity and salts concentration levels models gave predicting re-watering levels in percentage, also gave values of dilute irrigation point for Chinese red 9.05 or $10.00 \mathrm{ds} \mathrm{m}^{-1}$ and Chinese green 6.67 or $5.66 \mathrm{ds} \mathrm{m}^{-1}$. At resulted dilution points, plants of both cultivars were under high salt stress, which emphasized the need to re-water or dilution of salts for the survival of plants. The most effective predicting re-watering level and dilute irrigation point of both cultivars were found in same regime, so these models findings were very credible and meaningful. Higher dilute irrigation value of Chinese red indicates its more tolerance ability than Chinese green. Model's equations also gave direct irrigation point of Chinese red 1.32 or $1.62 \mathrm{ds} \mathrm{m}^{-1}$ and Chinese green 2.07 or $0.38 \mathrm{ds} \mathrm{m}^{-}$ ${ }^{1}$. It was concluded that predicting re-watering levels, dilute and direct irrigation point help to get maximum production using saline water resources.
\end{abstract}

KEYWORDS: Water potential. Physiological capacitance. Leaf tensity. Plant growth.

\section{INTRODUCTION}

Salinity tolerance of plants is increasing in recent times due to increasing trend of scarcity of quality irrigation water. The availability of better quality irrigation water in most coastal areas is being challenged because of saltwater intrusion into ground water. Saltwater intrusion into ground water is the biggest cause of the contamination of irrigation water and can be defined as "saline water movement into freshwater aquifers and most often is caused by ground water pumping (BARLOW, 2003). Due to shortage of high quality available water, low quality water can be used to grow crops. Water uptake was decreased with ever increasing salt concentration in the irrigation water (SORIA; CUARTERO, 1997). It affect some morphological and physiological parameters (ROMEROARANDA et al., 2001). Plant survival under salt stress condition using a series of physiological and cellular processes has been described by (SHINOZAKI; YAMAGUCHI-SHINOZAKI, 2007). Therefore, plant salt stress resistance can be determined through their physiological characteristics.

Many researchers have described that water potential described plant water status which is decreased during salt stress (CHAITANYA et al., 2003; MUNNS et al., 2006; AMBEDE et al., 2012; WANG et al., 2012; BOUGHALLEB et al., 2016). Salt stress produces water deficiency in plants, which could be determined using their electrophysiological properties. Any tissue that is not separated from the transpiration path by an infinite hydraulic resistance can serve as a capacitor (BLACKMAN; BRODRIBB, 2011) and this process is called physiological capacitance. It was found by many researchers that leaf water status can be describes with physiological capacitance and resistance (ABRAHAM et al., 2000; MEINZER et 
al., 2003). Leaf tensity was new aspect that was used to decrebied leaf water status in the plant during stress (ZHANG et al., 2015). The authors found a significant trend between water potential and physiological capacitance. As a result, the water status in leaves may be obtained from the variations of physiological capacitance.

Re-watering of plants after high salt stress should give positive response of plant water status and plant growth development. Many researchers have done work using different concentration of saline water and have examined their responses for different crops (KADAYIFCI; TUYLU, 2004; NAGAZ et al., 2012; NAGAZ et al., 2013; TURHAN et al., 2014; AL-HARBI et al., 2015; RAMESHWARAN et al., 2016). According to their findings, they suggest some crops, which are good in responses to moderate stress conditions while others gave good responses under slight and high salinity levels. Many researchers examined the response of plant under salt stress followed by rewatering with pure water (BOGEAT-TRIBOULOT et al., 2007; GALLE; FELLER, 2007; MONTANARO et al., 2007; PÉREZ-PÉREZ et al., 2007; GOMES et al., 2008; LUO et al., 2008). However, little information regarding dilution of salted water was found in literature. Re-watering or dilution of salted water is new technique to utilized saline water resources.

Okra (Abelmoschus esculentus L.) is an important vegetable crop, which is widely grown in all parts of the tropics, including temperate regions (ABID et al., 2002). It is classified as a moderately salt tolerant vegetable crop (MAAS; HOFFMAN, 1977). Salt stress reduced okra yield (SHAHID et al., 2011). However, little information is available in literature on how far different physiological attributes in okra are regulated by salt stress. This study aimed to examine the response of two okra cultivars under different levels of salt stress and rewatering with respect to their growth parameters and water status (water potential, physiological capacitance, leaf tensity). Based on the results, models were formulated to predict the response of okra to salt stress and re-watering levels for optimized plant growth.

\section{MATERIAL AND METHODS}

\section{Plant material and culture condition}

This experiment was performed at the School of Agricultural Equipment Engineering, Jiangsu University, Zhenjiang, Jiangsu province, China $\left(32.20^{\circ} \mathrm{N}, \quad 119.45^{\circ} \mathrm{E}\right)$, from June to September, 2015. Seeds of two okra (Abelmoschus esculentus L.) cultivars (Chinese red and Chinese green) were germinated in seed beds with mixture containing vermiculite, perlite and peat moss (2:1:1 $\mathrm{v} / \mathrm{v} / \mathrm{v})$. Pots were kept under greenhouse conditions under average of temperature $25^{\circ} \mathrm{C}$ and $60 \%$ relative humidity. During germination periods seeds were watered with Hoagland solution (HOAGLAND; ARNON, 1950). This experiment was carried out with three replications. After two weeks, seedlings were transfer into plastic pot of $9 \mathrm{~cm}$ diameter and $11 \mathrm{~cm}$ height containing perlite as a growing medium. Different concentration of saline water was made in Hoagland culture solution, equal amount of $\mathrm{NaCl}$ and $\mathrm{CaCl}_{2}$ were added into Hoagland culture solution, like control $(0 \%), 0.6 \%, 1.2 \%, 1.8 \%$ as show in (Table 1), chemical concentration of different treatment levels are shown in (Table 2). This experiment was arranged in a completely randomized design with 12 healthy and uniform seedlings from each cultivar of okra plants. When plant had four fully expended leaves then four treatment of saline water with different concentrations were applied. Plants were exposed for saline water for 21 days, after that plants that were receiving water $0.6 \%, 1.2 \%, 1.8 \%$ were rewatered with $0.6-0 \%, 1.2-0.6 \%, 1.8-1.2 \%$ respectively. This was regarded as re-watering phase and re-watering continued until 28 days.

Table 1. Different treatment levels

\begin{tabular}{lccc}
\hline Treatment & $\boldsymbol{E C}\left(\mathrm{ds} \mathrm{m}^{-1}\right)$ & $\begin{array}{c}\mathbf{1 L} \text { Hoagland culture } \\
\text { medium in the amount } \\
\text { of } \mathbf{~ N a C l ~}\left(\mathbf{g ~ L ~}^{-\mathbf{1}}\right)\end{array}$ & $\begin{array}{c}\mathbf{1 L} \text { Hoagland culture } \\
\text { medium in the amount } \\
\text { of } \mathbf{C a C l}_{\mathbf{2}}\left(\mathbf{g ~ L ~}^{-\mathbf{1}}\right)\end{array}$ \\
\hline 0 & 2.08 & 0.0 & 0.0 \\
$0.6 \%$ & 10.33 & 3.0 & 3.0 \\
$1.2 \%$ & 18.00 & 6.0 & 6.0 \\
$1.8 \%$ & 25.70 & 9.0 & 9.0 \\
\hline
\end{tabular}

\section{Growth parameter measurement}

After salt stress and re-watering, treatments plant height, stem diameter and leaf area were measured. Plant height was measured with the help of tape. Stem diameter was measured with the help of caliper. Leaf area of the selected leaves was 
measured with the help of leaf area meter (Handheld Laser Leaf Area Meter, CI, 203). At the end of salt stress and re-watering treatment plants of every level was cut at ground level and put into oven dried at $82^{\circ} \mathrm{C}$ to a constant dry weight and weighted to find dry weight of plant.

Table 2. Chemical characteristics of the treatments water

\begin{tabular}{|c|c|c|c|c|c|c|c|c|}
\hline \multirow{2}{*}{ Treatment } & \multirow{2}{*}{$E C\left(\mathrm{ds} \mathrm{m}^{-1}\right)$} & \multirow{2}{*}{ pH } & \multicolumn{6}{|c|}{ Ion concentration $\left(\mathrm{mmol} \mathrm{L}^{-1}\right)$} \\
\hline & & & $\mathbf{K}^{+}$ & $\mathrm{Na}^{+}$ & $\mathrm{Ca}^{2+}$ & $\mathrm{Mg}^{2+}$ & $\mathrm{Cl}^{-}$ & $\mathrm{SO}_{4}$ \\
\hline 0 & 2.08 & 5.55 & 6.00 & 40.00 & 4.00 & 2.00 & 2.00 & 2.05 \\
\hline $0.6 \%$ & 10.33 & 4.31 & 6.00 & 91.00 & 31.00 & 2.00 & 56.00 & 2.05 \\
\hline $1.2 \%$ & 18.00 & 4.35 & 6.00 & 142.66 & 58.06 & 2.00 & 110.12 & 2.05 \\
\hline $1.8 \%$ & 25.70 & 4.40 & 6.00 & 194.00 & 85.09 & 2.00 & 164.19 & 2.05 \\
\hline
\end{tabular}

\section{Water potential}

Leaves in salt stress phase and re-watering phase were used for the determination of water potential. Leaf water potential was measured with dew point micro voltmeter in a C-52-SF universal sample room (Psypro, Wescor, USA).

\section{Physiological capacitance}

The leaf physiological capacitance $(C P)$ was measured using an LCR tester (3532-50, HIOKI, Japan). The voltage and frequency used were $1 \mathrm{~V}$ and $3 \mathrm{kHz}$, respectively, which also choose by (KSENZHEK et al., 2004).

\section{Calculation of leaf tensity}

Leaf tensity can be calculated using (Zhang et al., 2015) method and using that equations are shown below.

$$
\begin{aligned}
& \frac{d}{A}=\frac{z_{0}\left[\left[81+\frac{\left(\sigma_{1}-a\right) M W}{180 P i R T}\right]\right.}{C P} \\
& \text { And } \\
& y=\frac{d}{A}=\frac{z_{0}}{C P}\left[81+\frac{(81-a) M W}{1000 \mathrm{E} R T}\right]
\end{aligned}
$$

For a given material, the relative dielectric constant $(a)$ and the molecular mass $(M)$ of the cytosol solute were given values. The leaf tensity of the plants $=1 / y$ was determined to indicate the water status in the leaf. In this study, the sugar $\mathrm{C}_{12} \mathrm{H}_{22} \mathrm{O}_{11}$ was identified as the solute in the cytosol; therefore, $a$ was $3.3, M$ was $342, T$ was $\left(\mathrm{K}, \mathrm{T}=273+T^{\circ} \mathrm{C}\right), R$ was gas constant $\left(0.0083 \mathrm{~L} \mathrm{MPa} \mathrm{mol}^{-1} \mathrm{~K}^{-1}\right)$ and $i$ was dissociation coefficient equal to 1 .

\section{Model construction}

Using the hyperbolic equation to construct the relationship between the plant dry weight (biomass) $D W$ and leaf physiological capacitance $C P$ and leaf tensity $L T$ are shown in equation 3 and 4. Here $m_{1}, m_{2}, n_{1}, n_{2}, D W_{01}$ and $D W_{02}$ are constant.

$$
\begin{aligned}
& D W=D W_{01}+\frac{m_{1} C P}{n_{1}+C P} \\
& D W=D W_{02}+\frac{m_{2} L T}{m_{2}+L T}
\end{aligned}
$$

Using the exponential decay equation to construct model between salt stress levels and leaf physiological capacitance $C P$, also construct model between salt stress levels and leaf tensity $L T$ are shown in equation 5 and 6 . Here $a_{1}, a_{2}, b_{1}, b_{2}$ are constants and $X_{E C}$ are the salt concentrations in the form electrical conductivity.

$C P=a_{1} e^{-b_{1} x_{E C}}$

$L T=a_{2} e^{-b_{2} X_{E C}}$

Direct irrigation point can be calculated like $C P=3 n_{1}, L T=3 n_{2}$. Put these $C P$ and $L T$ values into equation 5 and 6 , get the direct irrigation point in the form of $X_{E C}$.

Dilute irrigation point can be calculated using $C P=$ $n_{1}, L T=n_{2}$. Put these $C P$ and $L T$ value into equation 5 and 6 get the dilute irrigation point in the form of $X_{E C}$.

\section{Prediction of re-watering levels}

Using the exponential decay equation to construct model between salt stress levels in the form of percentage $\%\left(X_{C}\right)$ and leaf physiological capacitance $C P$ or leaf tensity $L T$ are shown in equation 7 and 8 .

$C P=a_{1} e^{-b_{1} x_{C}}$

$L T=a_{2} e^{-b_{2} z_{C}}$

Here $a_{1}, a_{2}, b_{1}, b_{2}$ are constants and $X_{C}$ are the salt concentrations in the form of percentage (\%). Predictions of re-watering levels were calculated using equations 7 and 8 . Put the values of $C P$ and $L T$ that getting through after re-watering, into equation 7 and 8 then getting predicted re-watering levels.

\section{Statistical analysis}

All measurements were subjected to analysis of variance (ANOVA) to distinguish significant differences (defined as $\mathrm{P} \leq 0.05$ ) between 
group means. Data are shown as the mean \pm standard error (SE). These mean data were analyzed statistically using SPSS software (version 17.0, SPSS Inc.) and mean results were compared through LSD post hoc test at 5\% significance level $(\mathrm{P}<$ $0.05)$.

\section{RESULTS AND DISCUSSION}

\section{Water status parameters}

Salt stress and re-watering influence water potential and physiological capacitance $(C P)$ of both okra cultivars are shown in (Table 3 ). In every salt stress level, the water potential and physiological capacitance of both cultivars were found to have decreased significantly. Chinese red had less decreased value of water potential at $0.6 \%$ and $1.2 \%$ salt stress level as compared to Chinese green but at $1.8 \%$ salt stress level Chinese red had more decrease in water potential than Chinese green due to negative effect by salt stress. In salt stress at $0.6 \%$, $1.2 \%$ both cultivars had non-significant value. The $C P$ value of Chinese red at $0.6 \%$ and $1.2 \%$, while Chinese green at $1.2 \%$ and $1.8 \%$ was nonsignificant between these two levels under salt stress. Plants differ in their leaf water potential and physiological capacitance response to salt stress. The physiological capacitance of both okra cultivars at $0.6 \%$ salt stress level decreased and water potential also decreased, which caused increased in solute concentration in the cytosol (ZHANG et al., 2015). The water potential became independent of water at $1.2 \%$ salt stress level of both okra cultivars, while physiological capacitance decreased only in Chinese green, which indicates that the concentration of solute in the cytosol was affected in Chinese green but Chinese red solute concentration was not affected. However at $1.8 \%$ salt stress level physiological capacitance and water potential decreased in Chinese red, which indicates that concentration of solute in the cytosol could have a threshold value of dysfunction of cells and decreasing water potential was plant method of survival when water loss is continue (MCCULLOH et al., 2014).

In re-watering, both cultivars showed recovery in different levels between water potential and physiological capacitance. Water potential at $1.8-1.2 \%$ increased by $53 \%$ in Chinese red and at $1.2-0.6 \%$ increased by $43 \%$ but water potential at $0.6-0 \%$ increased by $55 \%$ in Chinese green and at $1.2-0.6 \%$ showed $42 \%$ increase. Chinese red showed non-significant result of water potential between $0 \%$ and $0.6-0 \%$, also $1.2-0.6 \%$ and 1.8 $1.2 \%$, on the other hand, Chinese green showed non-significant values between $0.6-0 \%$ and 1.2$0.6 \%$ levels. Chinese red showed good recovery of $C P$ at $1.2-0.6 \%$ and $0.6-0 \%$, but Chinese green showed only better result at $0.6-0 \%$ due to its sensitive nature. At 1.8-1.2\% level increased was non-significant of both cultivars. In the re-watering phase at $0.6-0 \%$ level physiological capacitance and water potential of both okra cultivars increased which indicates solute concentration of cytosol was decreased. Water potential of Chinese red at 1.2$0.6 \%$ and $1.8-1.2 \%$ was increased but physiological capacitance increased only at $1.2-0.6 \%$, it means only solute concentration of cytosol at $1.2-0.6 \%$ was decreased. Increase in water potential at $1.8-1.2 \%$ was as a result of the decreased in the concentration of salts in plant leaf (MAKSIMOVIĆ et al., 2010; SALEEM et al., 2011; SHAHID et al., 2011). Similar results showed that as the Chinese green at $1.2-0.6 \%$ the water potential increased, the physiological capacitance remained unchanged. The cooprative changes in leaf physiological capacitance and water potential allow plant to cope with salt stress and re-watering.

Leaf tensities $L T$ of Chinese red and Chinese green were calculated with equation 2 and leaf tensity $=1 / y$, using the values of water potential and $C P$. The temperature was $25^{\circ} \mathrm{C}$. Leaf tensities of both cultivars were decreased as increased salt stress; this showed salt stress had great impact on leaf tensity. Leaf tensity can be used to describe the water status of plants and changes in tensity can reflect the speed of water loss and ability to hold water (IROGOYEN et al., 1992). The abilty of holding water was found to have been associated with the ressitance of plant during stress (HURD, 1974). The result of (Table 3) show that leaf tensity of Chinese red changed and the ability of the plant to hold water was better during salt stress and also shows the ability to recover from higher stress during re-watering. While the leaf tensity of Chinese green decreased sharply during salt stress, its abiltiy to hold water was not very good. During rewatering, Chinese green only show better recovery of leaf tensity at $0.6-0 \%$, due to its sensistive nature. Chinese red exhibited better ability to ressit salt stress and recover well during re-watering than Chinese green. 
Table 3. Water status parameter during salt stress and re-watering

\begin{tabular}{|c|c|c|c|c|c|}
\hline \multicolumn{6}{|c|}{ Water potential of two okra cultivars within salt stress and re-watering (MPa) } \\
\hline Treatment & $E C\left(\mathbf{d s ~ \mathrm { m } ^ { - 1 }}\right)$ & Red (salt stress) & $\begin{array}{l}\text { Red (re- } \\
\text { watering) }\end{array}$ & $\begin{array}{c}\text { Green (salt } \\
\text { stress) }\end{array}$ & $\begin{array}{l}\text { Green (re- } \\
\text { watering) }\end{array}$ \\
\hline 0 & 2.08 & $-1.19 \pm 0.21 \mathrm{a}$ & $-1.12 \pm 0.15 \mathrm{a}$ & $-0.94 \pm 0.03 a$ & $-0.71 \pm 0.01^{\mathrm{a}}$ \\
\hline $0.6 \%$ & 10.33 & $-2.21 \pm 0.08 b$ & $-1.20 \pm 0.19 \mathrm{a}$ & $-2.40 \pm 0.05 b$ & $-1.10 \pm 0.16 \mathrm{~d}$ \\
\hline $1.2 \%$ & 18.00 & $-2.46 \pm 0.23 b$ & $-1.40 \pm 0.16 b$ & $-2.69 \pm 0.05 b$ & $-1.40 \pm 0.20 \mathrm{~d}$ \\
\hline $1.8 \%$ & 25.70 & $-4.00 \pm 0.28 c$ & $-1.90 \pm 0.12 b$ & $-3.44 \pm 0.11 \mathrm{c}$ & $-2.00 \pm 0.33 b$ \\
\hline \multicolumn{6}{|c|}{ Physiological capacitance of two okra cultivars within salt stress and re-watering $\left(\mathrm{pF} \times 10^{-12}\right)$} \\
\hline Treatment & $E C\left(\mathbf{d s ~ \mathrm { m } ^ { - 1 }}\right)$ & Red (salt stress) & $\begin{array}{c}\text { Red (re- } \\
\text { watering) }\end{array}$ & $\begin{array}{l}\text { Green (salt } \\
\text { stress) }\end{array}$ & $\begin{array}{l}\text { Green (re- } \\
\text { watering) }\end{array}$ \\
\hline 0 & 2.08 & $93.00 \pm 1.72 \mathrm{a}$ & $90.93 \pm 2.08 \mathrm{a}$ & $98.06 \pm 0.77 \mathrm{a}$ & $95.33 \pm 0.33^{\mathrm{a}}$ \\
\hline $0.6 \%$ & 10.33 & $22.33 \pm 0.21 b$ & $31.03 \pm 1.24 \mathrm{~d}$ & $13.23 \pm 1.83 b$ & $26.50 \pm 1.75 \mathrm{~d}$ \\
\hline $1.2 \%$ & 18.00 & $19.46 \pm 1.56 b$ & $43.16 \pm 1.22 \mathrm{f}$ & $3.40 \pm 0.05 c$ & $4.58 \pm 0.10 \mathrm{c}$ \\
\hline $1.8 \%$ & 25.70 & $1.73 \pm 0.31 \mathrm{c}$ & $4.39 \pm 0.16 \mathrm{c}$ & $1.33 \pm 0.31 \mathrm{c}$ & $2.47 \pm 0.05 \mathrm{c}$ \\
\hline \multicolumn{6}{|c|}{ Leaf tensity of two okra cultivars within salt stress and re-watering $\left(\mathrm{cm} \times 10^{-3}\right)$} \\
\hline Treatment & $E C\left(\mathbf{d s ~ \mathrm { m } ^ { - 1 }}\right)$ & Red (salt stress) & $\begin{array}{l}\text { Red (re- } \\
\text { watering) }\end{array}$ & $\begin{array}{c}\text { Green (salt } \\
\text { stress) }\end{array}$ & $\begin{array}{l}\text { Green (re- } \\
\text { watering) }\end{array}$ \\
\hline 0 & 2.08 & $154.10 \pm 0.05 \mathrm{a}$ & $149.10 \pm 0.05 \mathrm{a}$ & $156.20 \pm 0.57 \mathrm{a}$ & $147.20 \pm 0.57 \mathrm{a}$ \\
\hline $0.6 \%$ & 10.33 & $44.20 \pm 0.05 b$ & $55.45 \pm 0.08 \mathrm{~d}$ & $27.10 \pm 0.56 \mathrm{~b}$ & $43.26 \pm 0.11 \mathrm{e}$ \\
\hline $1.2 \%$ & 18.00 & $30.10 \pm 0.08 \mathrm{c}$ & $78.66 \pm 0.06 \mathrm{e}$ & $7.40 \pm 0.57 \mathrm{c}$ & $8.40 \pm 0.56 c$ \\
\hline $1.8 \%$ & 25.70 & $5.20 \pm 0.11 \mathrm{~d}$ & $8.60 \pm 0.08 c$ & $3.30 \pm 0.56 \mathrm{~d}$ & $5.10 \pm 0.57 \mathrm{~d}$ \\
\hline
\end{tabular}

The means \pm SE in the table indicated the significant difference during salt stress and re-watering at $\mathrm{P} \leq 0.05$, according to one way ANOVA and LSD test.

\section{Plant growth}

Plant growth parameters that were considered in the study were significantly reduced by salt stress of both okra cultivars. During the salt stress phase, significantly reduction in plant height, leaf area, stem diameter and dry weight of both cultivars were observed as shown in (Table 4). More reduction at $1.8 \%$ salt stress level was observed in both cultivars as compared to control. Chinese green showed more reduction in plant growth parameters at $1.2 \%$ and $1.8 \%$ stress level but Chinese red showed more decrease at $1.8 \%$ stress level. Growth parameters were found to have decreased with increasing salinity (SHAHID et al., 2011). A large amount of salt in the water, its increases potential in the root zone and diffusion produces in the leaf cell and plant water uptake was decreased due to turgor loss (ASHRAF; HARRIS, 2004; MUNNS; TESTER, 2008). This process decreased water potential and cell elongation (De Oliveira et al., 2013). The decrease in water potential due to salt stress caused reduction in cell growth (IQBAL; ASHRAF, 2005), shoot growth and also causes inhibition cell expansion (CHAITANYA et al., 2003) and finally plant growth were affected in (Table 4). The results of this study related to water potential and plant growth parameters agreed with the findings (YOUSIF et al., 2010; WANG et al., 2012; KHAN et al., 2013). At 1.8\% salt stress level growth parameters of both cultivars were inhibition due to higher concentration of salts plant cannot tolerate high concentration of salt in their cytoplasm, so they may have been severe physiological dysfunction leading to decreased growth rate and finally cell death leading to dead whole plant (AMBEDE et al., 2012).

After salt stress treatments of okra cultivars, re-watering or dilution of salts gave a positive effect on plant growth. Plants had got its recovery from decreasing phase and moved towards increasing phase, which showed that tolerance of plant up to some extent point. Plant height; stem diameter, leaf area and dry weight increased after re-watering due to decreased amount of salt in dilute solution in (Table 4). Chinese red showed more recovery at 1.2$0.6 \%$ and $0.6-0 \%$ levels; in these levels, recovery was greater than control. It shows better ability to recover from higher stress. Chinese green only showed better result at $0.6-0 \%$ level due to its sensitive nature. Water potential, physiological capacitance and leaf tensity of Chinese red at 0.6$0 \%$ and $1.2-0.6 \%$ were increased gives positive effect of plants growth parameters and more increase was found in plant height. Water potential of Chinese green was increased at 1.2-0.6\% and 0.6$0 \%$ re-watering levels but physiological capacitance and leaf tensity were increased only $0.6-0 \%$ rewatering level. The increased in water potential in due to negative correlation of salt concentration with water potential that was found (PÉREZ-PÉREZ et $a l ., 2007)$. Leaf area of Chinese green at 1.2-0.6\% did not recover well reason for which physiological capacitance was not found to have increased because it depend upon leaf water store ability 
(MCCULLOH et al., 2014). According to the result showed that recovery in physiological capacitance and leaf tensity helped plant to improve its growth during re-watering as compared to water potential. In 1.8-1.2\% re-watering level both cultivars growth parameters were not recovered well due to badly affected by salt stress. Water potential was increased of both cultivars at 1.8-1.2, but physiological capacitance and leaf tensity were not increased, giving reason that plant growth recovery was depend upon physiological capacitance and leaf tensity. Our result at $1.8-1.2 \%$ level agreed more than $50 \%$ collapsed of cells plant was not recovered after re-watering (BRODRIBB; HOLBROOK, 2005).

Table 4. Effect of salt stress and re-watering on growth parameters

\begin{tabular}{|c|c|c|c|c|c|c|c|c|c|c|}
\hline $\begin{array}{c}\text { Cultiva } \\
\text { rs }\end{array}$ & $\begin{array}{c}\text { Treatm } \\
\text { ent }\end{array}$ & $\begin{array}{c}\text { Plant } \\
\text { height } \\
\text { (cm) }\end{array}$ & $\begin{array}{l}\text { Leaf } \\
\text { area } \\
\left(\mathrm{cm}^{2}\right)\end{array}$ & $\begin{array}{c}\text { Stem } \\
\text { diamet } \\
\text { er(mm) }\end{array}$ & $\begin{array}{c}\text { Dry } \\
\text { weight } \\
\text { (g) }\end{array}$ & $\begin{array}{c}\text { Re- } \\
\text { wateri } \\
\text { ng } \\
\text { level }\end{array}$ & $\begin{array}{c}\text { increm } \\
\text { ent in } \\
\text { plant } \\
\text { height } \\
(\%) \\
\end{array}$ & $\begin{array}{c}\text { increm } \\
\text { ent in } \\
\text { leaf } \\
\text { area } \\
(\%) \\
\end{array}$ & $\begin{array}{c}\text { increm } \\
\text { ent in } \\
\text { stem } \\
\text { diamet } \\
\text { er }(\%) \\
\end{array}$ & $\begin{array}{c}\text { Increm } \\
\text { ent in } \\
\text { dry } \\
\text { weight } \\
(\%) \\
\end{array}$ \\
\hline \multirow[t]{4}{*}{ Red } & 0 & $\begin{array}{c}77.66 \pm \\
1.45 \mathrm{a}\end{array}$ & $\begin{array}{c}62.33 \pm \\
1.45 \mathrm{a}\end{array}$ & $\begin{array}{c}11.06 \pm \\
0.17 \mathrm{a}\end{array}$ & $\begin{array}{c}50.16 \pm \\
0.31 \mathrm{a}\end{array}$ & $0-0 \%$ & 26.70 & 45.80 & 19.80 & 16.14 \\
\hline & $0.6 \%$ & $\begin{array}{c}56.33 \pm \\
0.88 \mathrm{~b}\end{array}$ & $\begin{array}{c}51.00 \pm \\
0.57 \mathrm{~b}\end{array}$ & $\begin{array}{c}8.40 \pm 0 . \\
23 \mathrm{~b}\end{array}$ & $\begin{array}{c}40.12 \pm \\
0.02 \mathrm{~b}\end{array}$ & $0.6-0 \%$ & 32.90 & 26.00 & 17.60 & 15.08 \\
\hline & $1.2 \%$ & $\begin{array}{c}41.00 \pm \\
0.57 \mathrm{c}\end{array}$ & $\begin{array}{c}36.16 \pm \\
0.44 \mathrm{c}\end{array}$ & $\begin{array}{c}6.40 \pm 0 . \\
05 \mathrm{c}\end{array}$ & $\begin{array}{c}29.97 \pm \\
0.09 \mathrm{c}\end{array}$ & $\begin{array}{c}1.2- \\
0.6 \%\end{array}$ & 40.50 & 40.70 & 16.80 & 19.18 \\
\hline & $1.8 \%$ & $\begin{array}{c}27.00 \pm \\
0.57 \mathrm{~d}\end{array}$ & $\begin{array}{c}24.00 \pm \\
0.57 \mathrm{~d}\end{array}$ & $\begin{array}{c}6.00 \pm 0 . \\
06 \mathrm{~d}\end{array}$ & $\begin{array}{c}20.66 \pm \\
0.66 \mathrm{~d}\end{array}$ & $\begin{array}{c}1.8- \\
1.2 \%\end{array}$ & 15.10 & 14.10 & 6.20 & 13.88 \\
\hline \multirow[t]{4}{*}{ Green } & 0 & $\begin{array}{c}67.33 \pm \\
1.20 \mathrm{a}\end{array}$ & $\begin{array}{c}64.00 \pm \\
1.00 \mathrm{a}\end{array}$ & $\begin{array}{c}9.53 \pm 0 \\
14 \mathrm{a}\end{array}$ & $\begin{array}{c}43.13 \pm \\
0.23 \mathrm{a}\end{array}$ & $0-0 \%$ & 29.10 & 44.30 & 27.20 & 15.09 \\
\hline & $0.6 \%$ & $\begin{array}{c}49.53 \pm \\
0.72 b\end{array}$ & $\begin{array}{c}45.00 \pm \\
0.57 \mathrm{~b}\end{array}$ & $\begin{array}{c}8.26 \pm 0 \\
14 \mathrm{~b}\end{array}$ & $\begin{array}{c}29.70 \pm \\
0.35 b\end{array}$ & $0.6-0 \%$ & 24.90 & 31.80 & 15.70 & 23.12 \\
\hline & $1.2 \%$ & $\begin{array}{c}34.64 \pm \\
0.44 \mathrm{c}\end{array}$ & $\begin{array}{c}32.33 \pm \\
1.20 \mathrm{c}\end{array}$ & $\begin{array}{c}7.10 \pm 0 . \\
05 \mathrm{c}\end{array}$ & $\begin{array}{c}25.96 \pm \\
0.29 \mathrm{c}\end{array}$ & $\begin{array}{c}1.2- \\
0.6 \%\end{array}$ & 17.50 & 25.10 & 8.90 & 17.77 \\
\hline & $1.8 \%$ & $\begin{array}{c}25.62 \pm \\
0.31 \mathrm{~d} \\
\end{array}$ & $\begin{array}{c}19.66 \pm \\
0.33 \mathrm{~d} \\
\end{array}$ & $\begin{array}{c}5.86 \pm 0 . \\
08 \mathrm{~d}\end{array}$ & $\begin{array}{c}22.00 \pm \\
0.20 \mathrm{~d}\end{array}$ & $\begin{array}{c}1.8- \\
1.2 \% \\
\end{array}$ & 14.60 & 10.60 & 6.90 & 11.29 \\
\hline
\end{tabular}

The means \pm SE in the table indicated the significant difference in growth parameters during salt stress phase and afterwards the relative percent increment under re-watering at $\mathrm{P} \leq 0.05$, according to one way ANOVA and LSD test

\section{Model construction}

Using data of plant dry weight (biomass) $D W$ and physiological capacitance $C P$ construct a model using equation 3; also construct a model of plant dry weight and leaf tensity $L T$ using equation 4 as shown in (Table 5) of both cultivars. It came to know that the relationship between plant dry weight (biomass) $D W$ and physiological capacitance $C P$ or leaf tensity $L T$ could well characterize the relationship between water status and plant growth. Similarly, coefficient of determination $\left(\mathrm{R}^{2}\right)$ showed that relationship between leaf tensity $L T$ and plant growth could be better fitted by the equation as compared with the relationship between leaf physiological capacitance $C P$ and plant growth. In the equation 3 and $4, n_{1}$ and $n_{2}$ represent the maximum plant dry weight during salt stress.

Table 5. Model between plant dry weight (biomass) and leaf physiological capacitance or leaf tensity of both okra cultivars

\begin{tabular}{cccccc}
\hline Cultivars & Model type & Model equation & $\mathbf{R}^{2}$ & $\mathbf{n}$ & P \\
\hline Red & $D W-C P$ & $D W=18.42+\frac{43.67 C P}{34.24+C P}$ & 0.9143 & 12 & $<0.0001$ \\
& $D W-L T$ & $D W=16.19+\frac{46.42+L T}{54.14+L T}$ & 0.9568 & 12 & $<0.0001$ \\
\multirow{3}{*}{ Green } & $D W-C P$ & $D W=22.01+\frac{28.05 C P}{32.75+C P}$ & 0.9767 & 12 & $<0.0001$ \\
& $D W-L T$ & $D W=21.69+\frac{31.57 L T}{74.21+L T}$ & 0.9846 & 12 & $<0.0001$ \\
\hline
\end{tabular}


Using salt stress levels and data of plant physiological capacitance or leaf tensity build a model using exponential equations 4 and 5 as shown in (Table 6). It came to know that the relationship between salt stress levels in the form of electrical conductivity $\left(X_{E C}\right)$, also salt stress levels in the form of percentage $\%\left(X_{C}\right)$ and physiological capacitance
$C P$ or leaf tensity $L T$ can well characterize the relationship between leaf water status and salt stress levels. From coefficient of determination $\left(\mathrm{R}^{2}\right)$, showed that relationship between leaf tensity and salt stress levels $X_{E C}$ or $X_{C}$ can be better fitted with the exponential equation as compared with the relationship between $C P$ and salt stress levels.

Table 6. Model between salt stress levels and physiological capacitance or leaf tensity of both okra cultivars

\begin{tabular}{|c|c|c|c|c|c|}
\hline Cultivars & Model type & Model equation & $\mathbf{R}^{2}$ & $\mathbf{n}$ & $\mathbf{P}$ \\
\hline \multirow[t]{4}{*}{ Red } & $C P-X_{E C}$ & $C P=123.84 \exp ^{-0.14 X_{R C}}$ & 0.9690 & 12 & $<0.0001$ \\
\hline & $L T-X_{E C}$ & $L T=200.71 \exp ^{-0.18 X_{\text {se }}}$ & 0.9838 & 12 & $<0.0001$ \\
\hline & $C P-X_{C}$ & $C P=92.01 \exp ^{-1,94 X_{G}}$ & 0.9659 & 12 & $<0.0001$ \\
\hline & $L T-X_{C}$ & $L T=152.66 \exp ^{-1.78 N_{S}}$ & 0.9813 & 12 & $<0.0001$ \\
\hline \multirow[t]{4}{*}{ Green } & $C P-X_{E C}$ & $C P=161.08 \exp ^{-0.24 X_{s c}}$ & 0.9983 & 12 & $<0.0001$ \\
\hline & $L T-X_{E C}$ & $L T=240.71 \exp ^{-0.21 X_{z E}}$ & 0.9995 & 12 & $<0.0001$ \\
\hline & $C P-X_{C}$ & $C P=98.03 \exp ^{-3.28 X_{C}}$ & 0.9982 & 12 & $<0.0001$ \\
\hline & $L T-X_{C}$ & $L T=156.11 \exp ^{-2.85} \mathrm{~K}_{\mathrm{C}}$ & 0.9992 & 12 & $<0.0001$ \\
\hline
\end{tabular}

\section{Direct and dilute irrigation point of both cultivars}

According to plant dry weight model, parameters $n_{1}$ and $n_{2}$ represent maximum dry weight of the plant under salt stress further increase in the salt concentration led to decline of dry weight, so Putting the value $C P=n_{l}$ in the equation (Table 6) to get the salt stress level of dilute irrigation point $\mathrm{WDI}_{C P}$ in the form of electrical conductivity $X_{E C}$. Putting the value of $C P=3 n_{1}$, in the equation (Table
6) to get the salt stress level of direct irrigation point $\mathrm{WI}_{C P}$ in the form of electrical conductivity $X_{E C}$, multiple of three maximum dry weight parameter indicated the 3 times increment of the dry weight that lose during salt stress. Similarly substituting the value of $L T=3 n_{2}$ and $L T=n_{2}$ to get the salt stress level of direct $\mathrm{WI}_{L T}$ and dilute irrigation $\mathrm{WDI}_{L T}$ of both cultivars. The values of direct irrigation and diluted irrigation of both cultivars with the help of $C P$ and $L T$ were shown in (Table 7).

Table 7. Value of direct and dilute irrigation point of both okra cultivars based on physiological capacitance and leaf tensity $\left(\mathrm{ds} \mathrm{m}^{-1}\right)$

\begin{tabular}{ccccc}
\hline Cultivars & $\mathbf{W I}_{C P}$ & $\mathbf{W D I}_{C P}$ & $\mathbf{W I}_{\boldsymbol{L} T}$ & $\mathbf{W D I}_{\boldsymbol{L T}}$ \\
\hline Red & 1.32 & 9.05 & 1.62 & 10.00 \\
Green & 2.07 & 6.67 & 0.38 & 5.66 \\
\hline
\end{tabular}

Direct irrigation and dilute irrigation were almost same using $C P$ and $L T$ equation for Chinese red but Chinese green showed difference due to it sensitive behavior and larger cell size that effect leaf tensity values. Dilute irrigation point weather based on the leaf physiological capacitance or leaf tensity, were larger than the direct irrigation points because increased in salt stress concentration increase the inhibition of growth, when the dilute irrigation point was reached, beyond on that point growth inhibition was serious so must be used diluted water for irrigation. Dilution of irrigation point for Chinese red is significantly greater than the Chinese green, which shows that Chinese red leaf cell size was smaller than Chinese green that increased salt tolerant ability of Chinese red as compared to Chinese green. Direct irrigation point just gave water to the crops no matter it contain salt or not because it does not affect crop growth. When plant exposed to $6.65 \mathrm{ds} \mathrm{m}^{-1}$ or more than $10 \mathrm{ds} \mathrm{m}^{-1}$ (EC) of salinity $50 \%$ reduction was found in plant growth (ZENG; SHANNON, 2000; SIRINGAM et al., 2011; AREF, 2013). Our results related to Chinese green and Chinese red also agreed with that finding, because Chinese green showed sudden reduction in plant growth at $0.6 \%$ and Chinese red showed more reduction at $1.2 \%$. During re-watering Chinese green showed good recovery at $0.6-0 \%$ and Chinese red showed better results at $1.2-0.6 \%$. Dilute irrigation point for Chinese green and Chinese red were also found in that regime where they showed better recovery during re-watering, so dilution point is the best prediction to start re-watering or dilution of salts because in that point plants are under serious growth inhibition. 


\section{Method for predicting re-watering levels}

Predicting re-watering levels was calculated using model equations are shown in (Table 6) in the form of $X_{C}$. Using re-watering $C P$ and $L T$ values that are present at (Table 3). Put these values into model equations; and getting $X_{C}$ values, labeled $X_{C}$ with $X_{C^{-} C P}$ and $X_{C^{-} L T}$ as shown in (Table 8).

Table 8. Prediction of re-watering levels of both okra cultivars based on physiological capacitance and leaf

\begin{tabular}{|c|c|c|c|c|}
\hline \multirow{2}{*}{$\begin{array}{c}\text { levels } \\
(\%)\end{array}$} & \multicolumn{2}{|c|}{ Red } & \multicolumn{2}{|c|}{ Green } \\
\hline & $\begin{array}{c}X_{C-C P} \\
(\%) \\
\end{array}$ & $\begin{array}{c}X_{C-L T} \\
(\%) \\
\end{array}$ & $\begin{array}{c}X_{C-C P} \\
(\%) \\
\end{array}$ & $\begin{array}{c}X_{C-L T} \\
(\%) \\
\end{array}$ \\
\hline $0-0$ & 0.01 & 0.01 & 0.01 & 0.02 \\
\hline $0.6-0$ & 0.54 & 0.57 & 0.40 & 0.45 \\
\hline $1.2-0.6$ & 0.39 & 0.37 & 0.93 & 1.02 \\
\hline $1.8-1.2$ & 1.57 & 1.62 & 1.12 & 1.20 \\
\hline
\end{tabular}

Predicted re-watering salt stress levels based on $C P$ and $L T$ were almost same of both cultivars. In the absence of salt stress, both cultivars have predicted values near to zero, indicating that the present invention is credible. For Chinese red, in addition to the control (no salt stress), the lowest level of salt stress was $1.2 \%$ rehydration to $0.6 \%$ treatment, indicating that after Chinese red $1.2 \%$ salt stress, adaptability greatly enhanced, continue to use $0.6 \%$ saline irrigation, up to $0.39 \%$ of the adverse effects. Chinese green, in addition to control, the lowest level of salt stress is 0.6 to $0 \%$, due to its sensitive nature. The results of growth parameters of both cultivars were found better in that predicting re-watering levels so that indicating these predicting re-watering levels techiques are very credable. Best predicting re-watering levels and dilution points of both okra cultivars were also found in same regime that also strengthen our finding.

\section{CONCLUSIONS}

Increasing concentration of salts stress significantly affect plant growth parameters of both okra cultivars. More reduction was found in Chinese green but Chinese red showed little tolerance in salt stress levels.

Re-watering left positive effect on plant growth of both cultivars in different levels. Physiological capacitance and leaf tensity have strong relationship with plant growth parameters during salt stress and re-watering.

Dilute and direct irrigation model had predicted dilute and direct irrigation points which were 9.05 or $10 \mathrm{ds} \mathrm{m}^{-1}$ and 1.32 or $1.62 \mathrm{ds} \mathrm{m}^{-1}$ for
Chinese red while 6.67 or $5.66 \mathrm{ds} \mathrm{m}^{-1}$ and 2.07 or $0.38 \mathrm{ds} \mathrm{m}^{-1}$ for Chinese green. Therefore, plants of both cultivars have to re-water with diluted of salted water on respective dilution points because plants of both cultivars undergone severe salt stress beyond the limits.

Direct irrigation point plants have to irrigate with water without taking consideration of containing salts or not. These findings are based on salt concentration model in the form of electrical conductivity. In the absence of electrical conductivity model, predicting re-watering level model also showed same behavior of plants growth under different re-watering levels.

Dilute and direct irrigation model and predicting re-watering levels model resulted same for both cultivars, because both results were found almost in same regime, which confirms that both models were very reliable and meaningful. These models are best techniques to check salt tolerance limit between different varieties of plant. These models also have an important theoretical and practical meaning for using saline water to get maximum production.

\section{ACKNOWLEDGMENT}

This study was supported by the project of the National Natural Science Foundation of China (No. 31301243); the national key basic research program (973) special projects (2013CB956701), the Priority Academic Program Development (PAPD) of Jiangsu Higher Education Institutions, the research foundation for introduce talents of Jiangsu University (13JDG030).

RESUMO: Neste estudo, foram utilizados dois cultivares de quiabo, verde chinês e vermelho chinês para avaliar o estado da água e parâmetros de crescimento submetidos a estresse salino, adicionando $\mathrm{NaCl}$ e $\mathrm{CaCl} 2$ com a mesma proporção em solução de cultura de Hoagland a níveis de 0\%, 0,6\%, 1,2\%, 1,8\% e re-irrigação a níveis de 0,6-0\%, 
1,2-0,6\%, 1,8-1,2\%. O potencial de água medido e os valores de capacitância fisiológica foram utilizados para calcular a tensão das folhas. $\mathrm{O}$ estresse com sal reduziu significativamente os parâmetros de crescimento e de estado da água. $\mathrm{O}$ verde chinês mostrou mais redução em comparação ao vermelho chinês, mas em $1,8 \%$ a redução do estresse salino de ambas as cultivares foi quase a mesma. Re-rega tinha dado uma resposta positiva para ambas as cultivares para recuperar de maior sal estresse. Os valores de peso seco, capacitância fisiológica, tensão da folha e níveis de concentração de sais mostraram predizer níveis de irrigação em porcentagem, também apresentaram valores de ponto de irrigação diluído para vermelho chinês 9,05 ou 10,00 ds m-1 e verde chinês 6,67 ou 5,66 ds m-1. Nos pontos de diluição resultantes, as plantas de ambas as cultivares estavam sob alto estresse salino, o que enfatizou a necessidade de re-água ou diluição de sais para a sobrevivência das plantas. O nível de irrigação mais eficiente e o ponto de irrigação diluído de ambas as cultivares foram encontrados no mesmo regime, portanto, esses resultados foram muito confiáveis e significativos. Maior valor de irrigação diluída de vermelho chinês indica a sua capacidade de tolerância mais do que verde chinês. As equações do modelo também deram ponto de irrigação direta de vermelho chinês 1,32 ou 1,62 ds m-1 e verde chinês 2,07 ou 0,38 ds m-1. Concluiu-se que a previsão dos níveis de rega, o ponto de irrigação diluído e direto ajudam a obter a máxima produção usando recursos hídricos salinos.

PALAVRAS-CHAVE: Potencial hídrico, capacitância fisiológica, tensão foliar, crescimento vegetal

\section{REFERENCES}

ABID, M. et al. Response of Okra (Abelmoschus esculentus L.) to EC and SAR of Irrigation Water.

International Journal of Agriculture and Biology, v. 4, p. 311-314, 2002.

ABRAHAM, N. et al. Irrigation automation based on soil electrical conductivity and leaf temperature. Agricultural Water Management, v. 45, p. 145-157, 2000. ISSN 0378-3774.

AL-HARBI, A. R. et al. Salinity and Deficit Irrigation Influence Tomato Growth, Yield and Water Use Efficiency at Different Developmental Stages. International Journal of Agriculture \& Biology, v. 17, p. 241250, 2015. ISSN 1560-8530.

AMBEDE, J. G. et al. NaCl salinity affects germination, growth, physiology, and biochemistry of bambara groundnut. Brazilian Journal of Plant Physiology, v. 24, p. 151-160, 2012. ISSN 1677-0420.

AREF, F. Effect of saline irrigation water on yield and yield components of rice (Oryza sativa L.). African Journal of Biotechnology, v. 12, p. 3503-3513, 2013. ISSN 1684-5315.

ASHRAF, M.; HARRIS, P. Potential biochemical indicators of salinity tolerance in plants. Plant science, v. 166, p. 3-16, 2004. ISSN 0168-9452.

BARLOW, P. M. Ground Water in Fresh Water-salt Water Environments of the Atlantic. Geological Survey (USGS), 2003. ISBN 060795194X.

BLACKMAN, C. J.; BRODRIBB, T. J. Two measures of leaf capacitance: insights into the water transport pathway and hydraulic conductance in leaves. Functional Plant Biology, v. 38, p. 118-126, 2011. ISSN 14454416.

BOGEAT-TRIBOULOT, M.-B. et al. Gradual soil water depletion results in reversible changes of gene expression, protein profiles, ecophysiology, and growth performance in Populus euphratica, a poplar growing in arid regions. Plant physiology, v. 143, p. 876-892, 2007. ISSN 1532-2548.

BOUGHALLEB, F. et al. Growth, photosynthesis, water use efficiency, and osmoregulation of the wild species Astragalus gombiformis Pomel. Under water deficit. Brazilian Journal of Botany, v. 39, p. 147-156, 2016. ISSN 0100-8404.

BRODRIBB, T. J.; HOLBROOK, N. M. Water stress deforms tracheids peripheral to the leaf vein of a tropical conifer. Plant Physiology, v. 137, p. 1139-1146, 2005. ISSN 0032-0889. 
CHAITANYA, K. et al. Water stress effects on photosynthesis in different mulberry cultivars. Plant Growth Regulation, v. 40, p. 75-80, 2003. ISSN 0167-6903.

DE OLIVEIRA, A. B. et al. Comparison between the water and salt stress effects on plant growth and development. InTech 2013. ISBN 9535109332. https://doi.org/10.5772/54223

GALLE, A.; FELLER, U. Changes of photosynthetic traits in beech saplings (Fagus sylvatica) under severe drought stress and during recovery. Physiologia Plantarum, v. 131, p. 412-421, 2007. ISSN 1399-3054.

GOMES, F. P. et al. Photosynthetic limitations in leaves of young Brazilian Green Dwarf coconut (Cocos nucifera L.'nana') palm under well-watered conditions or recovering from drought stress. Environmental and Experimental Botany, v. 62, p. 195-204, 2008. ISSN 0098-8472.

HOAGLAND, D. R.; ARNON, D. I. The water-culture method for growing plants without soil. Circular. California Agricultural Experiment Station, v. 347, p. 1-32, 1950.

HURD, E. Phenotype and drought tolerance in wheat. Agricultural Meteorology, v. 14, p. 39-55, 1974. ISSN $0002-1571$.

IQBAL, M.; ASHRAF, M. Changes in growth, photosynthetic capacity and ionic relations in spring wheat (Triticum aestivum L.) due to pre-sowing seed treatment with polyamines. Plant Growth Regulation, v. 46, p. 19-30, 2005. ISSN 0167-6903.

IROGOYEN, J.; EMERICH, D.; SANCHEZ-DIAZ, M. Water stress induced changes in concentration of proline and total soluble sugars in nodulated alfalfa (Medicago sativa) plants. Physiologia Plantarum, v. 84, p. 55-60, 1992. ISSN 0031-9317.

KADAYIFCI, A.; TUYLU, G. The effects of irrigation water salinity on onion's bulb yield, evapotranspiration and soil's profile. Journal of Agricultural Sciences, v. 10, p. 45-49, 2004. ISSN 1300-7580.

KHAN, M. M. et al. Salinity effects on growth, electrolyte leakage, chlorophyll content lipid peroxidation in cucumber (Cucumissativus L.). International Conference on Food and Agricultural Sciences, 2013.

KSENZHEK, O.; PETROVA, S.; KOLODYAZHNY, M. Electrical properties of plant tissues: resistance of a maize leaf. Bulgarian Journal of Plant Physiology, v. 30, p. 61-67, 2004.

LUO, H. et al. Effects of Rewatering after Drought Stress on Photosynthesis and Yield during Flowering and Boll-Setting Stage of Cotton Under-Mulch-Drip Irrigation in Xinjiang. Acta Agronomica Sinica, v. 34, p. 171174, 2008. ISSN 0496-3490.

MAAS, E. V.; HOFFMAN, G. Crop salt tolerancel-current assessment. Journal of the irrigation and drainage division, v. 103, p. 115-134, 1977. ISSN 0733-9437.

MAKSIMOVIĆ, I. et al. Growth, ion composition, and stomatal conductance of peas exposed to salinity. Open Life Sciences, v. 5, p. 682-691, 2010. ISSN 2391-5412.

MCCULLOH, K. A. et al. The dynamic pipeline: hydraulic capacitance and xylem hydraulic safety in four tall conifer species. Plant, cell \& environment, v. 37, p. 1171-1183, 2014. ISSN 1365-3040.

MEINZER, F. et al. Whole-tree water transport scales with sapwood capacitance in tropical forest canopy trees. Plant, Cell \& Environment, v. 26, p. 1147-1155, 2003. ISSN 1365-3040.

MONTANARO, G.; DICHIO, B.; XILOYANNIS, C. Response of photosynthetic machinery of field-grown kiwifruit under Mediterranean conditions during drought and re-watering. Photosynthetica, v. 45, p. 533-540, 2007. ISSN 0300-3604.

MUNNS, R.; JAMES, R. A.; LÄUCHLI, A. Approaches to increasing the salt tolerance of wheat and other cereals. Journal of Experimental Botany, v. 57, p. 1025-1043, 2006. ISSN 0022-0957. 
MUNNS, R.; TESTER, M. Mechanisms of salinity tolerance. Annual review of plant biology, v. 59, p. 651681, 2008. ISSN 1543-5008.

NAGAZ, K. et al. Soil salinity, yield and water productivity of lettuce under irrigation regimes with saline water in arid conditions of Tunisia. International journal of Agronomy and Plant Production, v. 4, p. 892900, 2013. ISSN 2051-1914.

NAGAZ, K.; MASMOUDI, M. M.; MECHLIA, N. B. Impacts of irrigation regimes with saline water on carrot productivity and soil salinity. Journal of the Saudi Society of Agricultural Sciences, v. 11, p. 19-27, 2012. ISSN 1658-077X.

PÉREZ-PÉREZ, J. et al. Leaf water relations and net gas exchange responses of salinized Carrizo citrange seedlings during drought stress and recovery. Annals of Botany, v. 100, p. 335-345, 2007. ISSN 0305-7364.

RAMESHWARAN, P. et al. Effects of drip-irrigation regimes with saline water on pepper productivity and soil salinity under greenhouse conditions. Scientia Horticulturae, v. 199, p. 114-123, 2016. ISSN 0304-4238.

ROMERO-ARANDA, R.; SORIA, T.; CUARTERO, J. Tomato plant-water uptake and plant-water relationships under saline growth conditions. Plant Science, v. 160, p. 265-272, 2001. ISSN 0168-9452.

SALEEM, A.; ASHRAF, M.; AKRAM, N. Salt (NaCl)-Induced Modulation in some Key Physio-Biochemical Attributes in Okra (Abelmoschus esculentus L.). Journal of Agronomy and Crop Science, v. 197, p. 202-213, 2011. ISSN 1439-037X.

SHAHID, M. A. et al. Salt stress effects on some morphological and physiological characteristics of okra (Abelmoschus esculentus L.). Soil \& Environment, v. 30, p. 66-73, 2011. ISSN 2074-9546.

SHINOZAKI, K.; YAMAGUCHI-SHINOZAKI, K. Gene networks involved in drought stress response and tolerance. Journal of experimental botany, v. 58, p. 221-227, 2007. ISSN 0022-0957.

SIRINGAM, K. et al. Salt stress induced ion accumulation, ion homeostasis, membrane injury and sugar contents in salt-sensitive rice (Oryza sativa L. spp. indica) roots under isoosmotic conditions. African Journal of Biotechnology, v. 10, p. 1340-1346, 2011. ISSN 1684-5315.

SORIA, T.; CUARTERO, J. Tomato fruit yield and water consumption with salty water irrigation. Acta Horticulturae, v. 458, p. 215-219, 1997. ISSN 9066058102.

TURHAN, A. et al. The effect of different salinity levels on the yield and some quality parameters of garlic (Allium sativum L.). Journal of Agricultural Sciences, v. 20, p. 280-287, 2014. ISSN 1300-7580.

WANG, W.Y. et al. Effects of salt stress on water content and photosynthetic characteristics in Iris lactea var. Chinensis seedlings. Middle East Journal of Scientific Research, v. 12, p. 70-74, 2012.

YOUSIF, B. S. et al. Effect of salinity on growth, mineral composition, photosynthesis and water relations of two vegetable crops; New Zealand spinach (Tetragonia tetragonioides) and water spinach (Ipomoea aquatica). International Journal Of Agriculture and Biology, v. 12, p. 211-216, 2010.

ZENG, L.; SHANNON, M. C. Salinity effects on seedling growth and yield components of rice. Crop Science, v. 40, p. 996-1003, 2000. ISSN 1435-0653.

ZHANG, M. et al. Rapid Measurement of Drought Resistance in Plants Based on Electrophysiological Properties. Transactions of the ASABE, v. 58, p. 1441-1446, 2015. https://doi.org/10.13031/trans.58.11022 